\title{
Condensation processes in shallow platforms
}

\author{
Juan J. Gómez a , Sixto Fernández-López ${ }^{\text {b }}$ \\ ${ }^{a}$ Dpto. Estratigrafia, Fac. Ciencias Geologicas (UCM) e Instituto de Geologia Económica (UCM-CSIC), \\ Universidad Complutense, 28040-Madrid, Spain \\ ${ }^{b}$ Dpto. Paleontología, Fac. Ciencias Geologicas (UCM) e Instituto de Geologia Economica (UCM-CSIC), \\ Universidad Complutense, 28040-Madrid, Spain
}

Received August 9, 1993; revised version accepted March 2, 1994

\begin{abstract}
Sequence stratigraphy allows elucidation of the time-space relationships of deposits in sedimentary basins. However, the relative distribution of unconformities and condensed sections can neither be used as diagnostic criteria for particular palaeogeographic settings, nor as indicators of maximum regional transgressions. Condensation processes also occur in the shallowest portions of platforms and during maximum regression episodes. Three separate processes of condensation are here distinguished: stratigraphic, sedimentary and taphonomic. These three categories of condensation can be used to analyze patterns of sediment distribution, and also to estimate lateral and vertical variations in sedimentation rates. Contrary to the usual interpretation, the maximum values of rate of sedimentation and degree of accommodation of sediments, as well as the highest relative sea level, occur in the lowest levels of the shallowing-upward sequences. The distinction between these condensation processes allows one to predict that the degree of sedimentary and stratigraphic condensation will be higher towards the distal portions of the platforms, whereas the stratigraphic condensation processes without sedimentary condensation will show the maximum intensity and frequency in the shallowest portions of the platforms.
\end{abstract}

\section{Introduction}

Because of its economic utility, finding of criteria valid for correlation at a global scale is one of the biggest challenges in stratigraphy. Condensed sections are of particular interest because they can form distinctive stratigraphic levels, capable of use as key beds in wide sectors of the sedimentary basins. These beds can be easily identified by the presence of hard-grounds, omission stratigraphic surfaces (reflecting the lack of sedimentation), high concentration of planktic and benthic fossils (which may constitute mixed assemblages with fossils from two or more bio- zones), authigenic minerals (glauconite, phosphorite, siderite) which sometimes form crusts, intensive bioturbation, organic matter and concentrations of the platinum group elements such as iridium, etc. (Vail et al., 1987, 1991; Loutit et al., 1988; Van Wagoner et al., 1988).

Due to this supposed ease of recognition, condensed sections are one of the most sought-after features in the field by geologists (Doglioni et al., 1990; Jacquin et al., 1991; Rioult et al., 1991; Martire, 1992; Drummond and Wilkinson, 1993; Fels and Seyfried, 1993; Graciansky et al., 1993; Kidwell, 1993). Together with unconformities, condensed sections are used as key pieces for the 
identification of depositional sequences and they play an important role in stratigraphic correlation at a regional as well as at a global scale (Haq et al., 1988; Loutit et al., 1988).

The wide use of the EXXON group models has led to generalization of the false idea that condensed sections have been exclusively developed during transgressions and that condensation intervals should be interpreted as the result of transgressive maximums. However, this relationship between condensation and palaeobathymetry is equivocal. Condensed sections can be generated in very different palaeobathymetric conditions, from deep oceanic environments to emerged shelves, and in some shallow basins condensed sections represent the maximum regressive episodes (Miall, 1986; Fernández-López and Gómez, 1991; Kidwell, 1991).

The main error lies in the assumption that condensation is generated by only one cause: the absence of sediment supply in the distal portions of the platforms during maximum transgressions. In reality, condensation can result from the interaction of diverse factors: the decrease of the sedimentation rate, the decrease of the accumulation rate and the mixture of fossil assemblages, as we discuss below. Taking into account the influence of these three factors, three different categories of condensation-stratigraphic condensation, sedimentary condensation and taphonomic condensation - should be distinguished (Fig. 1).

\section{FACTORS}

-Decreasing of the sedimentation RATE

-Decreasing of the accumulation RATE

-Mixture of different age FOSSILS

\section{CATEGORIES}

-STRATIGRAPHIC CONDENSATION

\section{-SEDIMENTARY CONDENSATION}

-TAPHONOMIC CONDENSATION
Fig. 1. Depending on the intervening factors, condensation processes can be attributed to three different categories: stratigraphic condensation, sedimentary condensation, and taphonomic condensation.

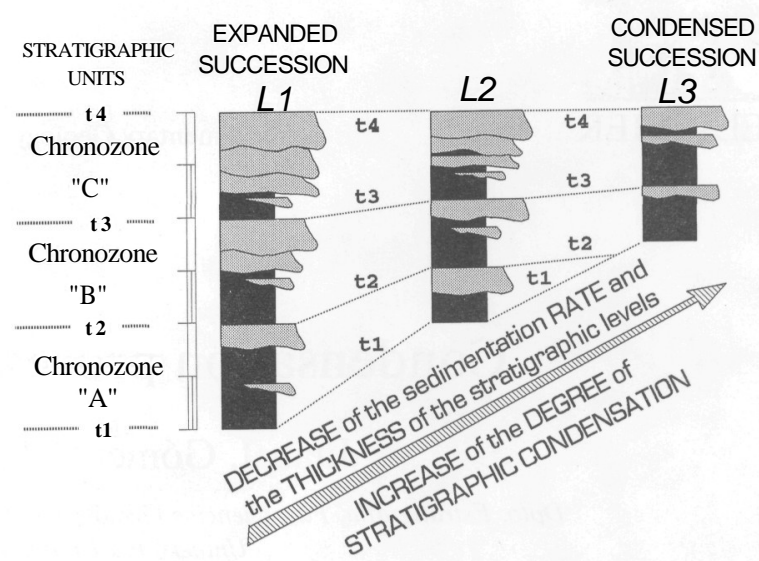

Fig. 2. Examples of a condensed section (L3) and an expanded section (L1), with respect to another section used as reference (L2). Thickness reduction of the stratigraphic intervals is due to a decrease of the sedimentation rate, and corresponds to an increase of the degree of stratigraphic condensation. The sequence of the Chronozone "A" is condensed in locality L2 with respect to locality L1 and is not represented in locality L3. The stratigraphic condensation process had a maximum intensity in locality L3, where this temporal interval corresponds to a hiatus.

\section{Stratigraphic condensation}

The term stratigraphic condensation, according to the meaning proposed by Heim (1934), has been subsequently employed to make reference to the decreasing thickness of any stratigraphic succession as a consequence of a lower to zero or negative sedimentation rate. A bed, horizon, level, stratigraphic sequence or succession is condensed if it is thinner than a contemporaneous stratigraphic succession used as reference. The concept of stratigraphic condensation has also been used for non-contemporaneous successions corresponding to equivalent temporal intervals. Other recent terms are condensed sections, condensed intervals and condensation intervals. For contrary results, the terms dilated sequences, extended successions or expanded successions have been used (Fig. 2).

The sedimentation rate corresponding to a stratigraphic interval is the relationship between the thickness of the interval and the time span in which the stratigraphic interval was formed. The value of the mentioned rate is often expressed in 
centimetres per million years or in analogous units. The terms rate of sedimentation (Schindel, 1982; Tipper, 1983; Bates and Jackson, 1987; Ricken, 1991), net sediment accumulation rate (Jenkyns, 1971; Tipper, 1986; Sadler and Strauss, 1990), accumulation rate (Dott, 1983; Tipper, 1986), and rate of sediment accumulation (Schindel, 1980, 1982) have been used for the same condition.

To estimate the lateral decrease of the sedimentation rate and to calculate the intensity of the condensation process, the following equation can be used:

$S T C=\left(1-\frac{T l}{T r}\right) 100$

where $S T C$ is the degree of stratigraphic condensation, $T l$ is the thickness of the local stratigraphic interval and $T r$ is the thickness of the stratigraphic interval used as reference. Said intervals may or may not belong to the same stratigraphic succession. The requirement for comparison is that they should correspond to temporal intervals of the same duration, even if they are of a different age. The stratigraphic condensation concept presupposes that the $T l$ value is lower than the $\operatorname{Tr}$ one. For calculation of these values, effects of differential compaction should be taken into account. The degree of stratigraphic condensation increases as the thickness of the local interval decreases. The maximum value $(100 \%)$ is reached if the local thickness becomes zero.

The variations of the degree of stratigraphic condensation (STC) should neither be confused with the variations of the relative sedimentation rate (i.e., $T l / T r$ ) nor with thickness difference $(T r-T l)$ nor with the proportion between the sedimentation rates reached during temporal intervals of equivalent duration $\left(V R_{l} / V R_{2}\right.$, where 1 and 2 are two different local stratigraphic intervals).

Another concept, more general than that of stratigraphic condensation one, is the lateral and/or vertical variation of the sedimentation rate $(V R$, or $S r$, in Ricken, 1991). For temporal intervals of equal duration, the relative variations of sedimentation rate can be numerically expressed as the ratio of the local stratigraphic thickness to the thickness of the reference section: $V R=T l / T r$. Index values lower than one correspond to condensed sections, whilst the expanded sections reach values higher than one. Once the relative variations of the sedimentation rates values are determined at the different localities, stratigraphic isorate contour maps can be traced. These maps are specially expressive in basins technically active during sedimentation.

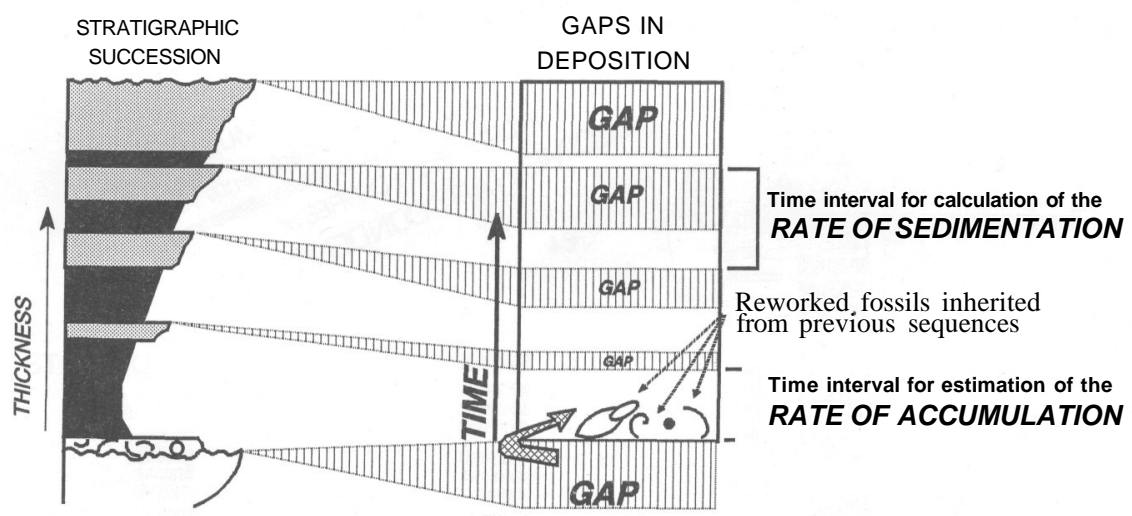

Fig. 3. Differences between rate of sedimentation and rate of accumulation, as a consequence of gaps in deposition within a shallowing-upward sequence. In this example, the rate of sedimentation of a stratigraphic interval is calculated by dividing the thickness of sediment by the total time interval including the gap after deposition. However, the rate of accumulation of a stratigraphic level can be estimated by dividing the thickness of sediment by the time interval of positive net sedimentation. The transgressive lag, located at the base of the sequence overlying the most important discontinuity contains reworked fossils which have been inherited from older sediments. 


\section{Sedimentary condensation}

For the calculation of sedimentation rate of a given stratigraphic level, time intervals of deposition as well as of non-deposition should be taken into account. This sedimentation rate is normally different from the rate of sediments accumulated per time unit between intervals of non-deposition (Fig. 3). For similar concept terms as "instantaneous rate of deposition" (Schindel, 1980; Tipper, 1983), "rate of deposition" (Dott, 1983; Sadler and Strauss, 1990) and "rate of positive net sedimentation" (Kidwell, 1985) have been mentioned.

The value of relative accumulation rate can easily be estimated in the geological record. Most geologists normally distinguish sediments deposited under low accumulation rate conditions (i.e. hemipelagites) as small thickness accumulated in great periods of time, and sediments deposited under high accumulation rate conditions (i.e. tempestites). For a given time interval, the amount of sediments accumulated by a tempestitic event will normally be higher than ano-

ther bed composed of hemipelagic sediments within the same basin.

The rock bodies thinner than other contemporaneous or of an equivalent temporal interval, due to a lower accumulation rate, are condensed sediments and the process generating them is sedimentary condensation. This process generates condensed sediments, fossiliferous or not, whilst the opposite results can be named as expanded sediments (Fig. 4). In the extreme case, sedimentary condensation produces condensed sediments formed during intervals of practically null sedimentation, mainly constituted by authigenic minerals and the remains of encrusting organisms.

Stratigraphic and sedimentologic data on the composition, texture and structure of the rock bodies, allow identification of their genesis and yield criteria to determine if sediments are condensed or expanded. For instance, in a given fining-upward sedimentary sequence, accumulation rate is higher for the tractive lower portions than for the finer upper pelitic ones.

The degree of sedimentary condensation concept $(S D C)$ is not synonymous with accumulation rate $(A)$. The relation between both variables can be expressed through the equation:

$S D C=\left(1-\frac{A l}{A r}\right) 100$

where $S D C$ is the degree of sedimentary condensation, $A l$ is the accumulation rate corresponding

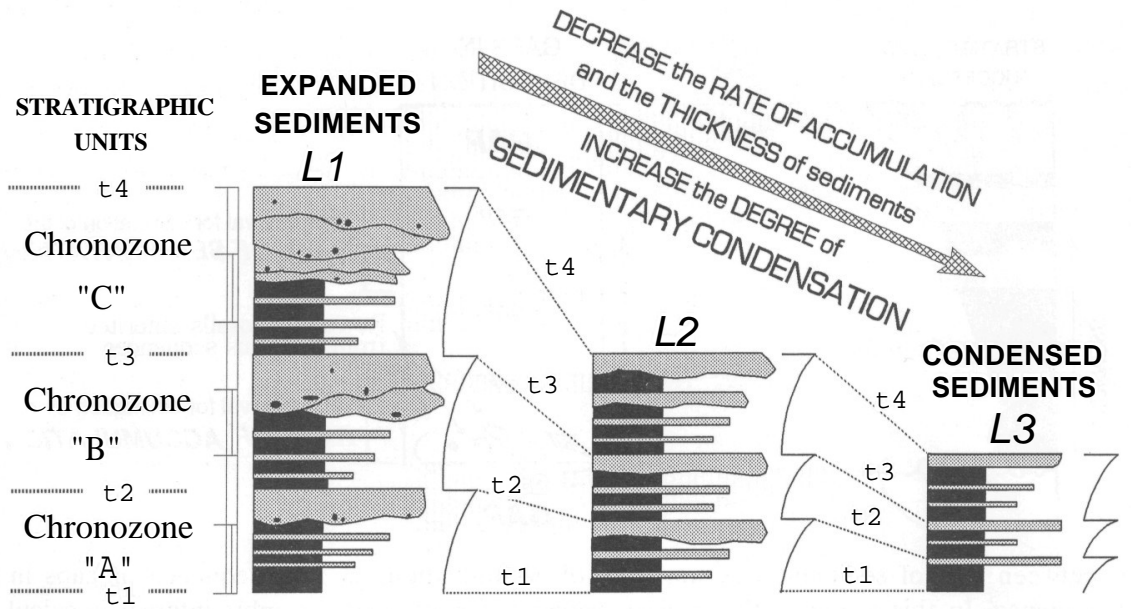

Fig. 4. Examples of condensed sediments (L3) and expanded sediments (L1), with respect to another locality taken as reference (L2). The increase of the sedimentary condensation from L1 to L3 results from a decrease in the rate of accumulation, and not due to the presence of hiatuses. In the present case, pelitic sediments (black in the figure) are in each locality sedimentary condensed with respect to the sandy deposits which were formed under conditions of higher accumulation rates. 
to the local rock body, and $A r$ is the accumulation rate of the rock body used as reference. As in the case with stratigraphic condensation, the compared rock bodies can be of the same stratigraphic succession or not, but sedimentary condensation supposes that the $A l$ value is lower than the $A r$ one. The degree of sedimentary condensation increases when the value of the accumulation rate decreases with respect to the accumulation rate used as reference. The maximum value $(100 \%)$ is reached once the local sedimentation becomes zero.

The lateral and/or vertical variation of the accumulation rate $(V A)$ is represented by the proportion between the value of the local accumulation rate $(A l)$ and the value of the accumulation rate used as reference $(A r): V A=A l / A r$. When this index is used, the condensed sediments represent values lower than one, whilst expanded sediments reach values higher than one.

It is also important to point out that a high degree of stratigraphic condensation does not imply that sediments have been deposited at low accumulation rates. For instance, some sequences showing stratigraphic condensation consist of tempestites which were formed at a high accumulation rate and consequently do not show sedimentary condensation (Fernández-López, 1985b; Brett and Baird, 1986). In these cases, the accumulation rate for each tempestite as well as the average one are high, but the rate of sedimentation of the stratigraphic interval is low (Fig. 5).

In summary, when the objective is to analyze the distribution patterns of sediments within a basin, the distinction between the sedimentary and stratigraphic condensation processes is needed.

\section{Taphonomic condensation}

One of the commonly employed criteria for the recognition of stratigraphic condensation has been the presence of mixed assemblages constituted by fossils of different age. However, the application of this criterion has lead to serious misinterpretations. The traditional reasoning is that the sedimentation time interval assigned to

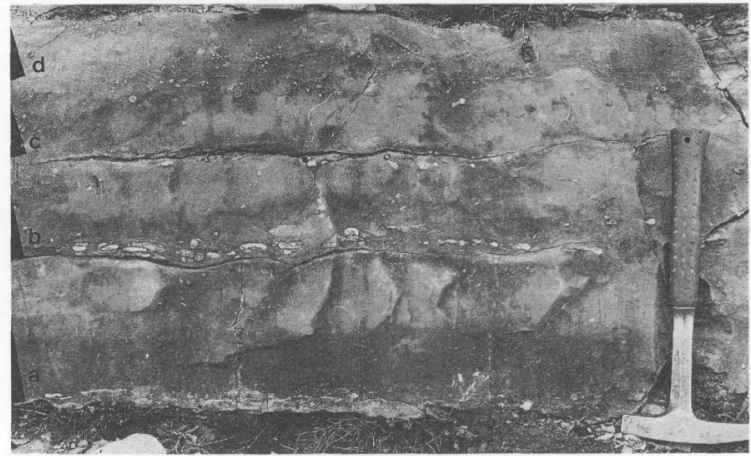

Fig. 5. Four amalgamated fining-upward sequences (a-d) on which the basal portions are characterized by high concentrations of reworked phosphatic fossils. From the mixed assemblages recorded at the base, these sequences gradually evolve upwards to bioclastic wackestones and mudstone carbonates. They are tempestites representing expanded sediments generated under high values of accumulation rate. As it will be seen in Sect. 4, these deposits contain condensed fossil assemblages and show taphonomic condensation. Exposure of lower Bajocian (Middle Jurassic) carbonates from the Iberian Range (Gea de Albarracin, Teruel, central Spain).

the level containing a mixed assemblage is equal to or greater than the time interval indicated by the fossils. For levels containing guide fossils from different ages, and only based on biostratigraphical criteria, low values of sedimentation and accumulation rates are assumed, designating them as condensed deposits. However, it must be noted that if the fossils were removed or displaced by natural agents from their place of origin and incorporated in recognizable form in a younger formation (i.e. reworked, Bates and Jackson, 1987) they cannot be used for dating (North American Commission on Stratigraphic Nomenclature, 1983) and, consequently, for estimation of the sedimentation or accumulation rates.

In order to recognize stratigraphic or sedimentary condensation in sections containing mixed assemblages, the distinction between reworked fossils and non-reworked fossils is necessary (Fernandez-Lopez, 1985a, 1991) as reworked fossils are older than the level where they are contained and resedimented fossils are contemporaneous with those levels. If reworked fossils are employed for dating a given stratigraphic level, the estimated time interval of sedimentation 
would be greater than actual and the estimated sedimentation rate would be lower than the actual rate.

Assemblages composed of mixtures of both reworked and resedimented fossils are condensed assemblages, but they do not have to represent stratigraphic or sedimentary condensation. Mixed assemblages can be considered as a reliable criterion for the recognition of stratigraphic or sedimentary condensation only if taphonomic observations are made.

Taphonomic condensation is the process of mixture of temporary successive remains of palaeobiological entities (Fernández-López, 1984, 1991). Taphonomic condensation produces condensed fossil assemblages, which can be generated in high-energy environments and can be found in expanded sediments formed under conditions of high accumulation rate. For instance, mixed assemblages of this type have been described as generated by erosion of anaerobic sea floors (Baird and Brett, 1986). Also expanded stratigraphic successions, which correspond to high values of sedimentation rate and are composed of sediments of high accumulation rate, can contain condensed fossil assemblages. This case can be corroborated, for instance, in some tempestites or turbidite sediments (Fig. 5). As a consequence, the degree of taphonomic condensation of an assemblage does not imply that such assemblage is found in horizons of stratigraphic condensation or in condensed sediments. It is important to point out that the taphonomic condensation concept can only be applied to the components of the fossil record, whilst the stratigraphic and sedimentary condensation concepts are, respectively, restricted to the superposed rock bodies and to the sediments of the stratigraphic record.

The degree of taphonomic condensation (TC) of an assemblage can be expressed by the number of chronostratigraphic or biostratigraphic units represented by the fossils of the assemblage. The degree of taphonomic condensation is a dimensional value, represented by the number of time units or units representing geologic time. On the contrary, the degrees of stratigraphic and the sedimentary condensation are expressed through dimensionless values.

\section{Condensation in sedimentary sequences}

The lack of distinction between stratigraphic, sedimentary and taphonomic condensation has led to erroneous interpretations in basin analysis. One of the most common mistakes is the interpretation of the shallowing-upward sequences characteristic of marine shelf environment. These shallowing-upward sequences, which normally also thicken and coarsen-upward (Fig. 6), are interpreted as the result of variations in three parameters: (1) the sedimentation rate; (2) the relative position of sea level; and (3) the degree of accommodation of the sediments. According to many authors, the lowest values in sedimentation rate, in any shallowing-upward sequence, are located in the lowermost portion of the sequence and the lowest relative sea level is represented in the upper levels. Following this interpretation, the highest values of sedimentation rate, the highest values of relative sea level and the highest values of the degree of accommodation of the sediments are recorded in the middle portion of each sequence.

However, what can be frequently observed is that the lowermost levels of these sequences contain fossils mixed from different biozones. These levels have traditionally been interpreted as condensed beds formed during a temporal interval of low values in sedimentation and accumulation rates. In reality these beds are not condensed but they include condensed fossil assemblages, generated under high-turbulence conditions, and their presence does not imply that they are contained in condensed levels or in condensed sediments (Fig. 7). At present, many of these condensed horizons have come to be interpreted as transgressive lags, indicators of deepening during the wide temporal interval of stratigraphic condensation (Fig. 8A). However, this interpretation of the platform sequence development should be modified.

Taking into account how the different strati- 


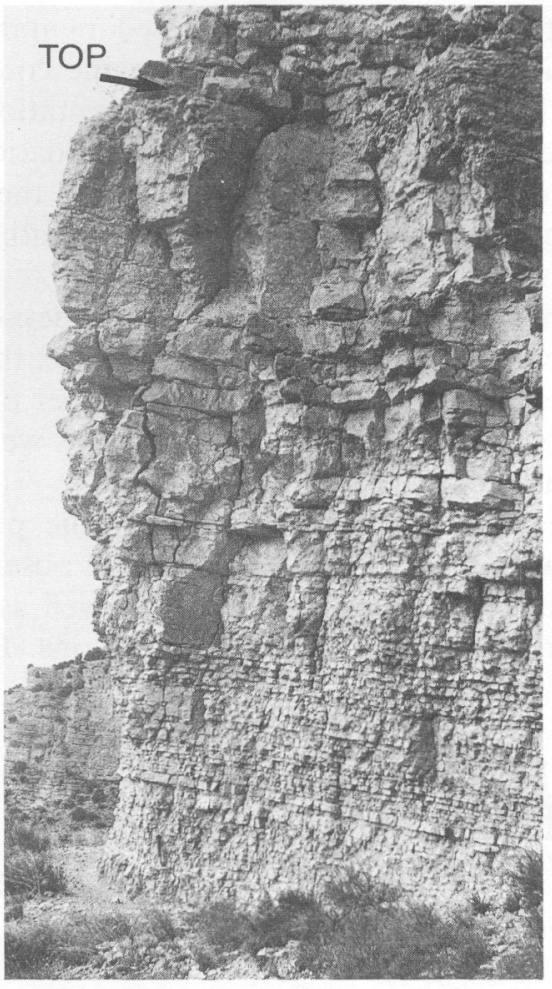

Fig. 6. Example of shallowing-upward sequence in Middle Jurassic (Aalenian-Bajocian) shallow platform carbonates from the Iberian Range in central Spain (Gea de Albarracin, Teruel). Bed thickness and grain-size increase towards the top from mudstone to packstone carbonates and clay content decreases towards the upper part. Total thickness of the sequence is $10 \mathrm{~m}$.

graphic levels constituting these shallowing-upward sequences were formed, it can be demonstrated that the lower portion of the sequence normally corresponds to soft-grounds, whilst the middle and upper portions were firm-grounds and even hard-grounds before burial. The successive levels of these sequences represent a trend on which the degree of consolidation was higher towards the younger levels. This trend can also be tested by variations in the taxonomic composition of the successive fossil assemblages. For instance, in the successive stratigraphic levels of each sequence, a gradual change of the benthic organisms is often observed, from the lower levels where assemblages of burrowers and depositfeeding or suspension-feeding endobionts are predominant, up to the upper levels which are dominated by assemblages with remains and/or traces of sessile epibionts, encrusting and/or boring organisms (cf. Matyja and Seilacher, 1985).

Another criterion to contrast the polarity between the different levels of the sedimentary sequence is the variation in the preservation stage of the fossils (Fernández-López and Suarez-Vega, 1979; Fernández-López, 1985b). For instance, the increase in the relative frequency of reworked fossils towards the upper part of the sequence has been proven as a very useful criterion for the sequential analysis of micritic sections or sediments showing quite homogeneous textural characters. Minor stratigraphic discontinuities, such as omission surfaces as well as remobilization surfaces (resulting from reworking), are also more frequent towards the upper part of the sequences, indicating that the values of the sedi-

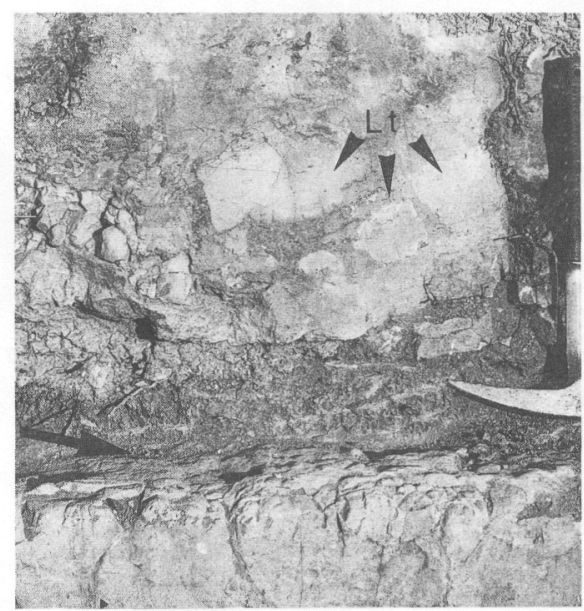

Fig. 7. Example of the base of a shallowing-upward sequence in carbonates. Surface marked by an arrow is a strongly bored hard-ground representing the top of the previous sequence. This level contains abundant lithoclasts $(L t)$ and condensed fossil assemblages composed of reworked and resedimented ammonites from eroded Toarcian and Aalenian sediments. These components are indicators of high sedimentation and accumulation rates due to turbulence. Although this level shows a high degree of taphonomic condensation, which can reach up to seven chronozones, it is not constituted by condensed sediments. The boundary between these two sequences coincides with the major regional Lias/Dogger unconformity in the Iberian Range (Hontanilla Creek, Teruel, central Spain). 
mentation rate decrease in the same direction (Fig. 8B).

The levels located at the base of the shallowing-upward sequences commonly contain condensed fossil assemblages. Contrary to the customary interpretation of this basal horizon, which shows textural features similar to the top of the previous sequence, this is a level formed in a brief interval of rapid sedimentation which occurred after a major gap. This level incorporates fossils and rock fragments inherited from older sediments and represents the beginning of the following sequence (Fernandez-Lopez and Gomez, 1990b; Savrda, 1991). The condensed fossil assemblages, or the so-called transgressive lags, commonly present at the base of these sequences do not imply stratigraphic or sedimentary condensation, but they show taphonomic condensation. The maximum values of sedimentation rate, relative depth and degree of accommodation correspond to the lowermost levels of these sequences, increasing the degree of stratigraphic condensation towards the top.

Although the levels containing condensed fossil assemblages are common at the base, they can also be present in the middle and upper portions of the shallowing-upward sequences as well as in sequences of other types (Fig. 9).

The here proposed polarity for the platform shallowing-upward sequences can be observed in the shallow platform sediments, as well as in the deeper distal portions of the platforms. But the

\section{EUSTATIC CURVE \\ SEDIMENTARY SEQUENCES}

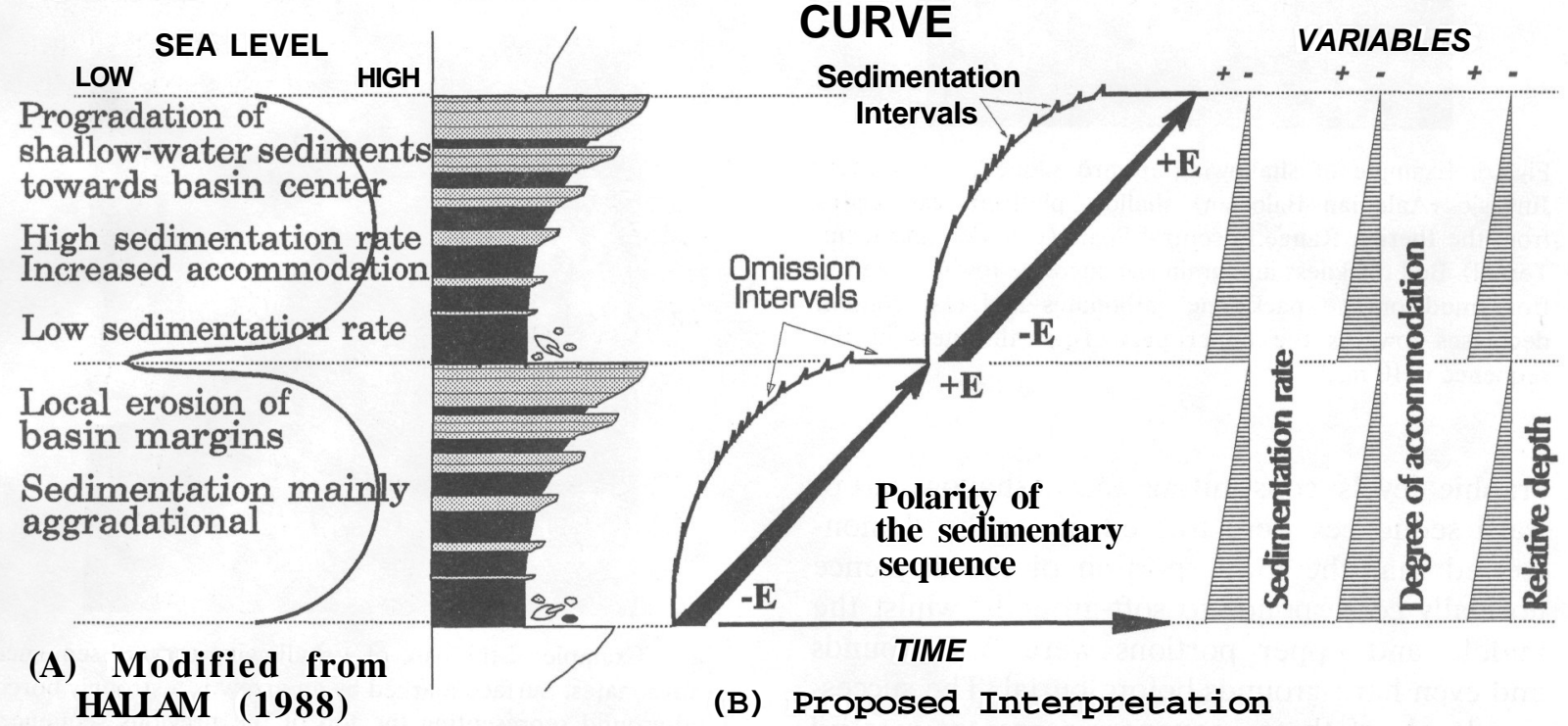

Fig. 8. Two different interpretations of the shallowing-upward sequences polarity, characteristics of the platforms, made by taking into account the sedimentation rate, the relative depth and the degree of accommodation. The lowermost levels of these sequences frequently contain condensed fossil assemblages with fossils from different chronozones. Based on that, many authors interpret them as condensed sediments and transgressive lags, indicators of maximum relative depth and minimum sedimentation rate (A). In reality they are condensed fossil assemblages indicating taphonomic condensation, but their presence in those levels does not imply that they are found in condensed levels or condensed sediments. The sedimentological, taphonomical and palaeoecological data allow the reconstruction of the sequential development curves (B). From these curves it can be seen that the polarity of these sedimentary sequences grades from the lowermost levels, where the maximum rates and relative depth values as well as maximum degree of accommodation of the sediments are recorded, up to the uppermost levels where these variables reach the minimum values. The polarity shown by these variables indicates a general increase in the hydrodynamic energy as well as in the turbulence levels of the depositional environment, from the lower portions $(-E)$ to the top of the sequences $(+E)$. 
polarity of these sequences is not contradictory with the accepted idea that overall sedimentation rates are generally higher in the shallow environments than in the deeper ones. At this respect it should be reminded that the values of sedimentation rates cannot be only deduced from the thickness of the sediments but also from the gaps between stratigraphic levels. In the upper terms of the sequences, sediments can be represented by thick levels having minimum values of sedimentation rates due to the greater non-deposition intervals.

\section{Condensation in shallow platforms}

Stratigraphic condensation as well as sedimentary condensation processes can be common in oceanic environments or during maximum transgression episodes, but they are not restricted to these environments and they are not diagnostic of deep bathymetric conditions. The commonly employed features to diagnose condensed levels, such as reworked concretions, ferruginous or phosphatic crusts, and extremely low sedimentation rates, among others, also occur in shallow environments and during regressive episodes. The stratigraphic condensation processes, without sedimentary condensation, have also been frequent in epicontinental shallow platforms and during episodes of maximum regional regression. Because of this, the duration represented by the condensed levels often increases towards the coastal areas.

The facies developed in the Iberian Range during the Lias/Dogger transition are a good example of condensed sections in shallow carbonate platforms, as they contain frequent stratigraphic condensation levels with abundant condensed fossil assemblages. These facies are mainly lime mudstones to wackestones and packstones with Zoophycos, characterized by the presence of abundant hard-grounds, omission surfaces, ferruginous crusts, authigenic minerals such as glauconite, ferruginous and/or phosphatic oolitic horizons, and condensed fossil assemblages with

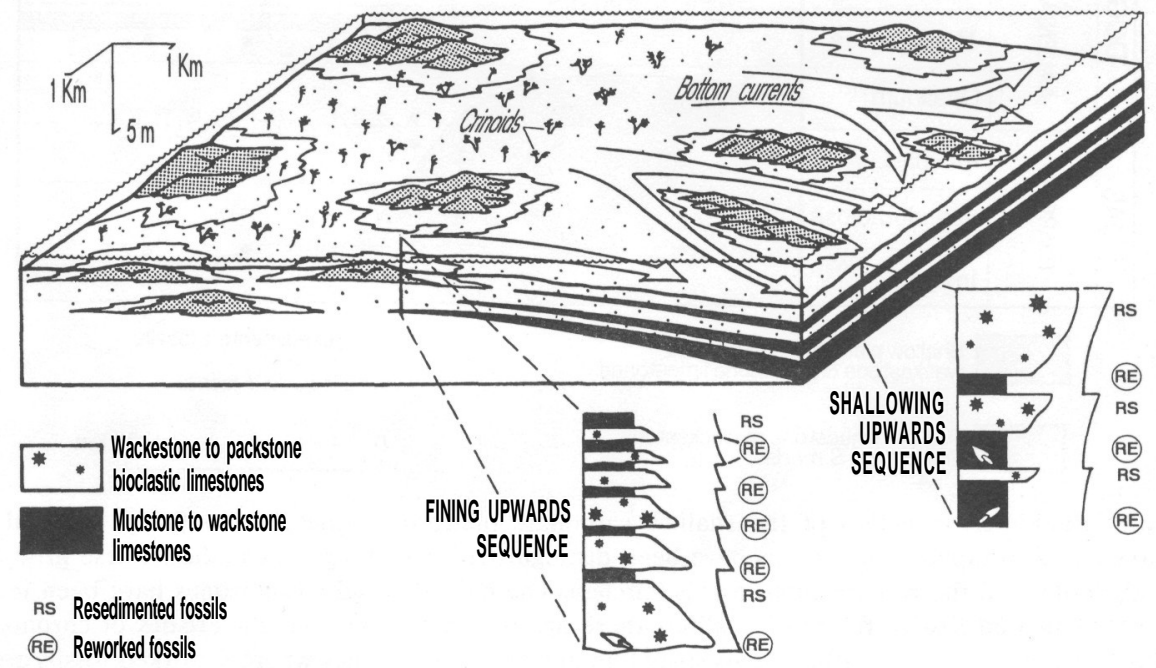

Fig. 9. Sketch of the carbonate platform developed during upper Bajocian in the Albarracin sector (Iberian Basin, central Spain). In shallow environments, sponges and algae buildups generated topographic highs on the sea bottom. In low hydrodynamic energy environments, carbonate claystones as well as lime mudstones with scarce skeletal remains were formed. In areas with higher hydrodynamic energy epibenthic organisms, in particular crinoids, were abundant and bioclastic carbonates (wackestone to packstone) were deposited. The sediments were organized in shallowing-upward sequences distributed along a wide area. However, filling of the depressions between buildups coupled with the action of the bottom currents locally generated fining-upward sequences. At the base of both types of sequences there are reworked fossils and condensed fossil assemblages, containing ammonites characteristics of several biozones, but they are neither condensed levels nor condensed sediments. 
high concentrations of ammonites representative of two or more chronozones. The degree of taphonomic condensation of some ammonites assemblages in the central sector of the Iberian Basin is of up to seven chronozones (Fig. 10). Some of these condensed fossil assemblages are contained in tempestites of centimetre thickness. According to sequence stratigraphy models, condensation would be associated with the deepest zones of the platform during the maximum transgression episodes. However, the condensed sections in this sector include carbonates containing omission stratigraphic surfaces, hard-ground surfaces, desiccation cracks, karstification surfaces, irregular rock-grounds, intraformational breccias, and geopetal filling of cavities formed by denudation and dissolution, which have been generated in very shallow subtidal and intertidal to emerged environments. Distribution of the Aalenian condensed sections as well as differences in hiatuses and degree of stratigraphic condensation was influenced by synsedimentary tectonics (FernándezLópez and Gómez, 1990a, c). As a consequence, the presence and distribution of condensed sections or levels, as well as the variation of their relative duration are not diagnostic criteria for palaeogeographic changes towards more oceanic or deeper conditions.

The condensed sections of the distal portion of the platforms and the condensed sections formed in the proximal ones are not necessarily the result of the same relative sea level changes. They can be due to different and reverse eustatic variations which would consequently be diachronous. The distinction between the stratigraphic and sedimentary condensation processes allows temporal

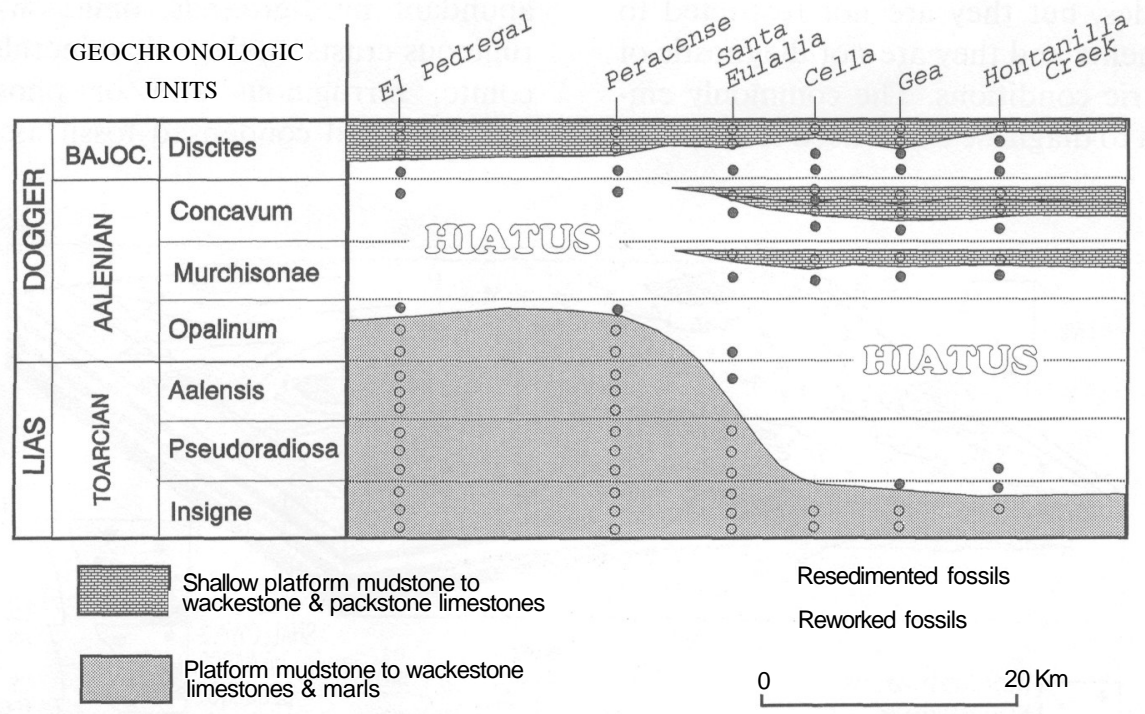

Fig. 10. Chronostratigraphic cross-section of the shallow carbonate platform in the Iberian Range (central Spain) during the Lias/Dogger boundary. Two taphonomic groups have been distinguished for dating rock bodies. These groups are composed by the reworked fossils (dots) and the resedimented fossils (circles). The biozones and chronozones have been identified taking only into account the resedimented fossils. In some localities there are reworked fossils characteristics of chronozones of which the stratigraphic record is not present (dots within hiatus space). In any of these localities where reworked fossils are present, the fossil assemblages represent longer temporal intervals than the rock bodies containing them. The upper Toarcian and lower Aalenian sediments correspond to shallow external platform facies, whilst the middle and upper Aalenian and lower Bajocian sediments represent very shallow subtidal to emerged facies. These Aalenian sediments are organized as shallowing-upward sequences and constitute an example of stratigraphic condensation in a very shallow platform due to low sedimentation rates, together with taphonomic condensation indicated by mixed fossil assemblages, but without sedimentary condensation. Differences in the hiatuses and degree of stratigraphic condensation between the El Pedregal-Peracense area (left) and the other localities (Santa Eulalia, Cella, Gea and Hontanilla Creek) are conditioned by the Noguera-Aguaton fault, which was active during sedimentation of the Lias/ Dogger. 
correlation between the condensed sections developed in the deep areas of the platform once they have been differentiated from the ones developed in the shallow areas of the shelf. The condensed sections of both types, deep and shallow, can be exclusively due to eustatic factors in which maximum intensity affected the basin synchronously. However, if during sequence analysis condensed sections formed in the proximal areas are confused with condensed sections formed in the distal ones, the temporal correlations can be as diachronous as correlation based on any lithostratigraphic unit developed in the platform.

\section{Conclusions}

The idea of condensation is useful for analyzingthe distribution patterns of the sediments in the basins, as well as for making stratigraphic correlations at a regional and global scale. However, the results of condensation can be due to the decrease of the sedimentation rate, the decrease of the accumulation rate and/or the mixture of fossil assemblages. Considering these three factors, processes of condensation of three different categories should be distinguished: stratigraphic condensation, sedimentary condensation and taphonomic condensation.

Stratigraphic condensation is the process of formation of rock bodies thinner than others of an equivalent temporal interval as a consequence of a low to zero sedimentation rate. When decreasing thickness is due to lower accumulation rate, the process is sedimentary condensation. Taphonomic condensation is the process of mixture of temporary successive remains and/or traces of palaeobiological entities.

Condensation concepts denote relationships between two or more sections, sediments or fossils and, consequently, cannot be applied to an individual deposit. Condensed sections or condensed sediments cannot be exclusively diagnosed by the presence of hard-grounds, omission surfaces, high concentrations of authigenic minerals, or mixed assemblages with fossils of different age. Moreover, the frequency of these observable features is not necessarily proportional to the degree of stratigraphic or sedimentary condensation.

Contrary to the most usual interpretation of the development of the shallowing-upward sequences, the maximum values of sedimentation rate, relative depth and degree of accommodation of the sediments in these sequences correspond to the basal levels, and the value of these variables decreases towards the top. In shallowing-upward sequences as well as in fining-upward sequences developed in shallow platforms, condensed fossil assemblages are frequently associated with maximum rate sedimentation events as indicated by taphonomic reworking. However, these conclusions are not incompatible with the fact that overall sedimentation rates in shallow platforms are generally higher than in the deeper distal portions of the platforms.

The relative distribution of unconformities and condensed sections cannot be used as diagnostic criteria for a particular palaeogeographic localization or of eustatic changes towards more oceanic or deeper conditions. During the maximum transgression episodes, condensation processes can occur in the distal portions of the platforms, but there are also condensation processes during the maximum regression episodes in the shallowest portions of the platforms. Distribution of condensed sections in shallow platforms can be strongly influenced by synsedimentary tectonics. The degree of stratigraphic condensation tends to be higher in the uplifted fault-controlled blocks than in the deeper surrounding areas.

The distinction between the three categories of condensation allows one to predict that the degree of sedimentary and stratigraphic condensation will be higher towards the distal portions of the platforms, mainly due to starvation, whilst the stratigraphic condensation processes without sedimentary condensation will show maximum intensity and frequency in the shallowest areas of the platforms, where winnowing processes are common.

If condensed sections of the distal portions of the shelf, generated during transgressive maxima, are indiscriminately correlated with the condensed sections of the proximal zones, due to 
regressive maxima, the temporal correlations will be as diachronous as the most progradational or retrogradational facies developed in the platform.

\section{Acknowledgements}

The authors greatly appreciate review and valuable suggestions on the manuscript by Dr. Samuel Root (The College of Wooster, Ohio) and Dr. A.D. Miall (Geology Department, University of Toronto). This study is a contribution to the Project "El Dogger de los Catalánides: escala cronoestratigráfica, estratigrafía secuencial y relaciones paleogeográficas con la Cuenca Ibérica" (DGICYT, P.B. 92-0011).

\section{References}

Baird, G.C. and Brett, CE., 1986. Erosion on an anaerobic seafloor: significance of reworked pyrite deposits from the Devonian of New York State. Palaeogeogr., Palaeoclimatol., Palaeoecol., 57: 157-193.

Bates, R.L. and Jackson, J.A., 1987. Glossary of Geology. American Geological Institute, Alexandria, Va., 788 pp.

Brett, C.E. and Baird, G.C., 1986. Comparative taphonomy: a key to paleoenvironmental interpretation based on fossil preservation. Palaios, 1: 207-227.

Doglioni, C, Bosellini, A. and Vail, P.R., 1990. Stratal patterns: a proposal of classification and examples from the Dolomites. Basin Res., 2: 83-95.

Dott, R.H., Jr., 1983. Episodic sedimentation-How normal is average? How rare is rare? Does it matter? J. Sediment. Petrol., 53: 5-23.

Drummond, C.N. and Wilkinson, B.H., 1993. On the use of cycle diagrams as records of long-term sea level change during accumulation of carbonate sequences. J. Geol., 22: 687-702.

Fels, A. and Seyfried, H., 1993. "A la recherche du temps perdu": on geological condensation, with examples from the Jurassic Subbetic Plateau in Southeastern Spain. Neues Jahrb. Geol. Palaeontol., Abh., 189: 13-31.

Fernández-López, S., 1984. Nuevas perspectivas de la Tafonomía evolutiva: tafosistemas y asociaciones conservadas. Estud. Geol., 40: 215-224.

Fernández-López, S., 1985a. Criterios elementales de reelaboración tafonómica en ammonites de la Cordillera Ibérica. Acta Geol. Hisp., 19: 105-116.

Fernández-López, S., 1985b. El Bajociense en la Cordillera Ibérica. Tesis Doctoral, Dpto. Paleontol., Univ. Complutense Madrid, $850 \mathrm{pp}$.
Fernández-López, S., 1991. Taphonomic concepts for a theoretical biochronology. Rev. Esp. Paleontol., 6: 37-49.

Fernández-López, S. and Gómez, J.J., 1990a. Evolution tectono-sédimentaire et genése des associations d'Ammonites dans le secteur central du Basin Ibérique (Espagne) pendant l'Aalénien. Cah. Univ. Cathol. Lyon, 4: 39-52.

Fernández-López, S. and Gómez, J.J., 1990b. Utilidad sedimentológica y estratigráfica de los fósiles reelaborados. In: S. Fernández-López (Coord.), Comunicaciones de la Reunión de Tafonomía y Fosilización. Dpto. Paleontol., Univ. Complutense Madrid, pp. 125-144.

Fernández-López, S. and Gómez, J.J., 1990c. Facies aalenienses y bajocienses, con evidencias de emersión y carstificación, en el sector central de la Cuenca Ibérica. Implicaciones paleogeográficas. Cuad. Geol. Ibér., 14: 67-111.

Fernández-López, S. and Gómez, J.J., 1991. Condensación: significados y aplicaciones al análisis de cuencas. Estud. Geol., 47: 169-181.

Fernández-López, S. and Suarez-Vega, L.C., 1979. Estudio bioestratigráfico (Ammonoidea) del Aaleniense y Bajociense en Asturias. Estud. Geol., 35: 231-239.

Graciansky, P.Ch., Dardeau, G., Dumont, Th., Jacquin, Th., Marchand, D., Mouterde, R. and Vail, P., 1993. Depositional sequence cycles, transgressive-regressive facies cycles, and extensional tectonics: example from the southern Subalpine Jurassic basin, France. Bull. Soc. Geol. Fr., 164: 709-718.

Hallam, A., 1988. A reevaluation of Jurassic eustasy in the light of new data and the revised Exxon curve. In: C.K. Wilgus, B.S. Hastings, C.G.S.C. Kendall, H. Posamentier, C.A. Ross and J.C. Van Wagoner (Editors), Sea-Level Changes: An Integrated Approach. SEPM Spec. Publ., 42: 261-273.

Haq, B.U., Hardenbol, J. and Vail, P.R., 1988. Mesozoic and Cenozoic chronostratigraphy and eustatic cycles. In: C.K. Wilgus, B.S. Hastings, C.G.S.C. Kendall, H. Posamentier, C.A. Ross and J.C. Van Wagoner (Editors), Sea-Level Changes: An Integrated Approach. SEPM Spec. Publ., 42: 71-108.

Heim, A., 1934. Stratigraphische Kondensation. Eclogae Geol. Helv., 27: 372-383.

Jacquin, T., Arnaud-Vanneau, A., Arnaud, H., Ravenne, C. and Vail, P.R., 1991. Systems tracts and depositional sequences in a carbonate setting: a study of continuous outcrops from platform to basin at the scale of seismic lines. Mar. Pet. Geol., 8: 122-139.

Jenkyns, H.C., 1971. The genesis of condensed sequences in the Tethyan Jurassic. Lethaia, 4: 327-352.

Kidwell, S.M., 1985. Palaeobiological and sedimentological implications of fossil concentrations. Nature, 318: 457-460.

Kidwell, S.M., 1991. Condensed deposits in siliciclastic sequences: expected and observed features. In: G. Einsele, W. Ricken and A. Seilacher (Editors), Cycles and Events in Stratigraphy. Springer-Verlag, Berlin, pp. 682-695.

Kidwell, S.M., 1993. Taphonomic expressions of sedimentary hiatuses: field observations on bioclastic concentrations 
and sequence anatomy in low, moderate and high subsidence settings. Geol. Rundsch., 82: 189-202.

Loutit, T.S., Hardenbol, J., Vail, P.R. and Baun, G.R., 1988. Condensed sections: the key to age determination and correlation of continental margin sequences. In: C.K. Wilgus, B.S. Hastings, C.G.S.C. Kendall, H. Posamentier, C.A. Ross and J.C. Van Wagoner (Editors), Sea-Level Changes: An Integrated Approach. SEPM Spec. Publ., 42: 183-213.

Martire, L., 1992. Sequence stratigraphy and condensed pelagic sediments. An example from the Rosso Ammonitico Veronese, northeastern Italy. Palaeogeogr., Palaeoclimatol., Palaeoecol., 94: 169-191.

Matyja, B.A. and Seilacher, A., 1985. Oyster beds: morphologic response to changing substrate conditions. In: U. Bayer and A. Seilacher (Editors), Sedimentary and Evolutionary Cycles. Springer-Verlag, Berlin, pp. 421-435.

Miall, A.D., 1986. Eustatic sea level changes interpreted from seismic stratigraphy: a critique of the methodology with particular reference to the North Sea Jurassic record. Am. Assoc. Pet. Geol. Bull., 70: 131-137.

North American Commission on Stratigraphic Nomenclature, 1983. North American stratigraphic code. Am. Assoc. Pet. Geol. Bull., 67: 841-875.

Ricken, W., 1991. Time span assessment-an overview. In: G. Einsele, W. Ricken and A. Seilacher (Editors), Cycles and Events in Stratigraphy. Springer-Verlag, Berlin, pp. 773794.

Rioult, M., Dugue, O., Du Chene, J., Ponsot, C, Fily, G., Moron, J.-M. and Vail, P.R., 1991. Outcrop sequence stratigraphy of the Anglo-Paris Basin Middle to Upper Jurassic (Normandy, Maine, Dorset). Bull. Cent. Rech. Explor.-Prod. Elf Aquitaine, 15: 101-194.
Sadler, P.M. and Strauss, D.J., 1990. Estimation of completeness of stratigraphical sections using empirical data and theoretical models. J. Geol. Soc, London, 147: 471-485.

Savrda, Ch.E., 1991. Teredolites, wood substrates, and sea-level dynamics. Geology, 19: 905-908.

Schindel, D.E., 1980. Microstratigraphic sampling and the limits of paleontologic resolution. Paleobiology, 6: 408-426.

Schindel, D.E., 1982. Resolution analysis: a new approach to the gaps in the fossil record. Paleobiology, 8: 340-353.

Tipper, J.C, 1983. Rates of sedimentation, and stratigraphical completeness. Nature, 302: 696-698.

Tipper, J.C, 1986. Estimating stratigraphic completeness. J. Geol., 95: 710-715.

Vail, P.R., Colin, J.P., Du Chene, R.J., Kuchly, J., Mediavilla, F. and Trifilieff, V., 1987. La stratigraphic séquentielle et son application aux corrélations chronostratigraphiques dans le Jurassique du basin de Paris. Bull. Soc. Géol. Fr., 8(3): 1301-1321.

Vail, P.R., Audemard, F., Bowman, S.A., Eisner, P.N. and Perez-Cruz, C, 1991. The stratigraphic signatures of tectonics, eustasy and Sedimentology - an overview. In: G. Einsele, W. Ricken and A. Seilacher (Editors), Cycles and Events in Stratigraphy. Springer-Verlag, Berlin, pp. 617659.

Van Wagoner, J.C, Posamentier, H.W., Mitchum, R.M., Jr., Vail, P.R., Sarg, J.F., Loutit, T.S. and Hardenbol, J., 1988. An overview of the fundamentals of sequence stratigraphy and key definitions. In: C.K. Wilgus, B.S. Hastings, C.G.S.C. Kendall, H. Posamentier, C.A. Ross and J.C Van Wagoner (Editors), Sea-Level Changes: An Integrated Approach. SEPM Spec. Publ., 42: 39-45. 